\title{
Dispositivo Experimentoteca de Matemática: produção na imanência
}

\section{Dispositif Experimentoteca de Matemática: production in immanence}

\author{
Margareth Aparecida Sacramento Rotondo* \\ Tamiris Taroco Marocco ${ }^{* *}$
}

\begin{abstract}
Resumo
O presente trabalho é fruto de uma pesquisa cuja intenção é investigar como são potencializados os modos de subjetivação através do dispositivo Experimentoteca de Matemática. Tal dispositivo foi acionado durante os encontros entre bolsistas de um projeto de Treinamento Profissional e escolares de uma escola da rede pública de Juiz de Fora. A pesquisa busca cartografar as linhas de fuga que foram potencializadas durante a produção matemática nas atividades propostas no projeto. Dessa forma, a pesquisa lança olhares para a ligação entre a aprendizagem matemática e os modos de subjetivação potencializados no aprender, ou seja, atenta para a seguinte noção: quando o escolar produz matemática, também é produzido por ela. Uma educação matemática na imanência-vida.
\end{abstract}

Palavras-chave: Dispositivo. Experimentação. Imanência. Educação Matemática.

\begin{abstract}
This study is the result of a research with the intention of investigating how the modes of subjectivation are potencialized through the dispositif Experimentoteca de Matemática. Such dispositif was triggered during a series of meetings between scholarship holders in a Professional Training project and students from a public school in Juiz de Fora. This research aims to trace the different escape routes reinforced during the working of math problems while the activities presented by the project were taking place. The research, therefore, considers the link between math learning and subjectivation modes that are enhanced through the learning process. In other words, this concept is focused on the notion that when a student produces math, he is also produced by it. It is a mathematic education in the immanence-life.
\end{abstract}

Keywords: Dispositif. Experimentation. Immanence. Mathematic Educati

"Doutora em Educação Matemática pela Universidade Estadual Paulista (UNESP). Professora da Faculdade de Educação e do Programa de Pós-Graduação em Educação da Universidade Federal de Juiz de Fora (UFJF). Coordenadora do Núcleo de Educação em Ciência, Matemática e Tecnologia (NEC/UFJF). Líder do Travessia, $\begin{array}{lllll}\text { Grupo de } & \text { Pesquisa } & \text { certificado } & \text { pelo } & \text { CNPQ }\end{array}$ http://dgp.cnpq.br/dgp/faces/grupo/visualizar/visualizar_grupo_pesquisa.jsf?faces-redirect=true. Pesquisadora FAPEMIG. Endereço para correspondência: Universidade Federal de Juiz de Fora - Faculdade de Educação Rua José Lourenço Kelmer, s/n - Campus Universitário Bairro São Pedro - CEP: 36036-900 - Juiz de Fora MG..E-mail: margarethrotondo@gmail.com.

${ }^{* * *}$ Graduanda em Pedagogia pela Universidade Federal de Juiz de Fora (UFJF). Bolsista de Iniciação Científica BIC/UFJF. Membro do grupo Travessia. Pesquisadora FAPEMIG. Endereço para correspondência: Rua José Lourenço Kelmer, s/n - Campus Universitário Bairro São Pedro - CEP: 36036-900 - Juiz de Fora - MG. . E-mail tamiristaroco@gmail.com. 


\title{
1 Introdução ${ }^{1}$
}

\begin{abstract}
Encontros de sextas-feiras ${ }^{2}$
"Salve o Corinthians,/O campeão dos campeões,/Eternamente/Dentro dos nossos corações." Em tom alto, um corpo-adolescente vai ao nosso encontro. Cantarola o Corinthians. Carrega a camisa rubro-negra do Flamengo ao corpo. Corpo-adolescente. Magro, braços compridos, alto, risonho, falante, cantarolante. "Salve o Corinthians, $/ O$ campeão dos campeões,/Eternamente/Dentro dos nossos corações”. Anuncia sua chegada cantandovestindo uma subversão: um corinthiano-flamenguista, um flamenguista-corinthiano? Intriga. Cantarola, sorri, perturba, incomoda. Assim se inicia o último encontro do grupo de alguns bolsistas do Treinamento Profissional de um dos projetos da Faculdade de Educação da Universidade Federal de Juiz de Fora com alguns escolares de uma escola pública. "Salve o Corinthians,/O campeão dos campeões,/Eternamente/Dentro dos nossos corações".
\end{abstract}

Em nosso primeiro encontro estavam presentes os bolsistas do Treinamento Profissional (TP), a equipe executora da pesquisa ${ }^{3}$ e oito escolares. Tínhamos nomes próprios. Dos bolsistas e equipe: Tamiris, Margareth, João, Theysmara, Alizandra. Do espaço físico que ocupávamos, até então, concebíamos como: Experimentoteca de Matemática. Dos escolares:...

Fizemos uma roda e brincamos com nossos nomes próprios. Em círculo, o primeiro disse seu nome, o segundo disse o seu próprio nome e o do primeiro colega que estava à sua esquerda. O terceiro disse o seu nome próprio, o do segundo e o do primeiro que estavam à sua esquerda. E assim seguia, com cada um dizendo seu nome e dos dois que o antecediam pela esquerda. A falação-repetição corria o círculo, até que uma palma surgia pelas mãos da coordenadora da equipe e mudava-se a direção. Então, cada um dizia seu nome próprio, o nome próprio dos dois que o antecediam, não mais os da esquerda, agora os da direita. A falação-repetição imprimia ritmo às vozes, ao corpo, à memória. Em muitos instantes, o ritmo era quebrado, a memória escapava e os sorrisos invadiam o ar e estremeciam os corpos. Circulamos, repetimos, criamos uma música com nossos nomes próprios.

Outra proposta foi apresentada naquele dia: separarmo-nos em duplas e contarmos um pouco do que andávamos sendo, fazendo, do que gostávamos, do que não gostávamos, para o companheiro que nos escutava. Depois de um tempo reunidos nas duplas, retornaríamos ao círculo e apresentaríamos nosso colega.

\footnotetext{
${ }^{1}$ Este texto é uma versão revista e ampliada de uma Comunicação Científica apresentada no V Seminário Internacional de Pesquisa em Educação Matemática, realizado em outubro de 2012 em Petrópolis-RJ.

${ }^{2}$ No decorrer do texto, estarão presentes recortes de relatórios do campo de pesquisa, apresentados em formato distinto do texto. Chamamos esses recortes de Encontros de sextas-feiras e, através deles, tentaremos trazer a intensidade do vivido. Além disto, são apresentadas fotos de alguns momentos vividos na pesquisa, numa tentativa, ainda que minimalista, de trazer um tanto do que se dava no acontecer do campo.

${ }^{3}$ Mais adiante, no texto, a pesquisa será apresentada.

${ }^{4}$ Optamos por não apresentar os nomes dos escolares e, sim, os efeitos.
} 
Em uma grande mesa estavam dois escolares, menino e menina. Ela tentava conversar. Ele não respondia. Caras fechadas, incômodo. Findando o tempo combinado para a conversa, a coordenadora aproxima-se da dupla e abre algumas questões: "Vamos lá: o que você gosta de fazer, de comer? Para qual time você torce?”. A menina respondia. Ele balançava os ombros. "Qual cor você prefere?”. Ela: “Rosa”. Ele: “Azul”. Da menina vem: “O que digo a respeito dele?". Teve como resposta: “Diga que ele gosta de azul”. Dele vem uma lista do que a colega gostava de fazer, do que gostava de comer, para qual time torcia e de que cor gostava.

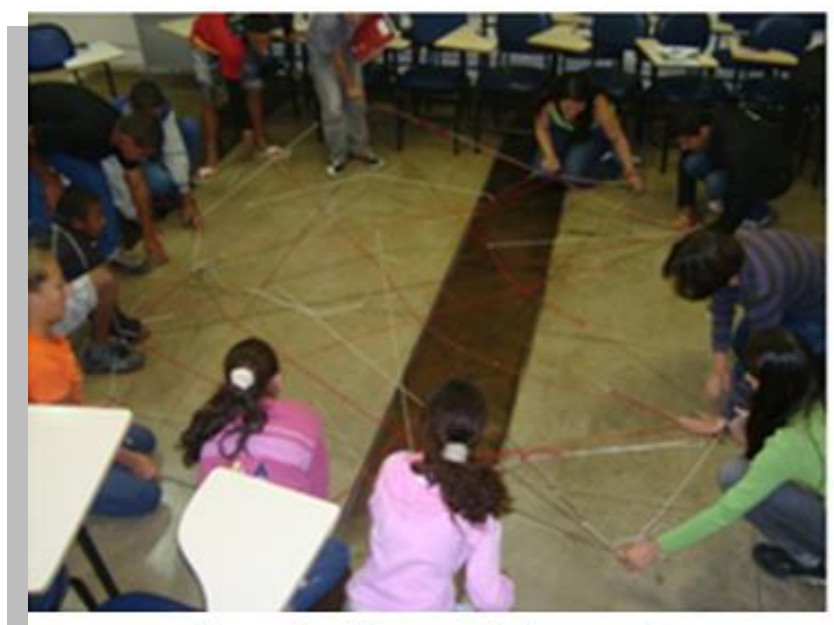

Figura 1 - Nomes próprios em rede.

Voltamos ao grupo maior. $\mathrm{Na}$ voz de cada: o companheiro de dupla. Nas mãos: um novelo de linha colorida ia nos ligando. Flamenguistas, cruzeirenses, vascaínos, adoradores de macarrão, de batata frita, de brincar na rua, de funk, de samba, de verde, de amarelo, de rosa, jogadores de futebol, trabalhadores. Nossas linhas surgiam. Um pouco dos territórios que vivíamos iam se mostrando, dito por outro. Um menino que gosta de azul foi apresentado. Nossos corpos sorriam. O menino que gostava de azul continuava sisudo. Nenhuma referência foi feita à escola, às disciplinas escolares e aos professores. Ao final tínhamos uma rede se compondo, ligando nossos corpos. “[...] o nome próprio não designa de modo algum uma pessoa ou um sujeito. Ele designa um efeito, um ziguezague, algo que passa ou que se passa entre dois como uma diferença potencial: “efeito Compton”, “efeito Kelvin” (DELEUZE e PARNET, 1998, p. 14)

Anunciar nossos nomes próprios produziu efeitos ziguezague. Algo passa. A experiência através do dispositivo Experimentoteca de Matemática. Efeito Tamiris. Efeito Margareth. Efeito João. Efeito Theysmara. Efeito Alizandra. Efeito... Efeito... Efeito menino que gosta de azul. Efeito Experimentoteca... A Experimentoteca de Matemática, um dispositivo. 
Encontros de sextas-feiras

$1^{\circ}$ Encontro. Digo quem sou, afirmo o que gosto, o que não gosto. (Ex)ponho-me através da língua. Sou (ex)posto na língua de outro. Entro em uma configuração na qual já não sei me enunciar, me anunciar, já não sei estabelecer meu lugar. "Sou aluno aqui? Posso falar? Posso rir?". "Como isso se dá?". "Como é ser bolsista aqui? Como devo fazer?". "Como é ser professor aqui? Não dá mais para exigir que falem, já que é o momento de falar. Não há como exigir o silêncio, já que é o momento de ouvir. Não dá mais para exigir que parem de rir e brincar, é isso que o corpo pede." Somos estrangeiros numa terra nova.

\section{Dispositivo: Experimentoteca de Matemática na imanência-vida}

Esta escrita apresenta uma pesquisa que atenta, particularmente, para duas noções: o discurso já constituído daquilo que é e a invenção instituinte em um sendo. O campo de pesquisa se compõe junto ao atendimento realizado por bolsistas de Treinamento Profissional a escolares de uma escola pública mineira.

As atividades matemáticas propostas aos escolares têm como objetivo potencializar modos outros de se conceber a Matemática e de produzi-la, desestabilizando os discursos constituídos do que é um aluno na situação de fracasso escolar. A entrada nesse campo de pesquisa busca compreender a ligação que se faz entre a aprendizagem matemática e os modos de subjetivação potencializados nesse aprender. Entendendo que, quando o escolar produz Matemática, também é produzido por ela, um sendo na imanência do viver, na imanência-vida. A pesquisa, desse modo, questiona: como são potencializados modos outros de existir através da experiência no dispositivo Experimentoteca de Matemática?

Nossa proposta, neste texto, é lançar mão da experiência e, com/através dela, ir atualizando, na escrita, os modos de aprendizagem que, naquele território existencial, iam sendo inventados.

Aqui já se faz questão: Experiência? Experimentoteca?

Experiência não é o experimento. Não é aquele que se faz seguindo caminhos, trilhas bem delineadas, com o intuito de chegar a uma meta pré-definida. Para nós, a experiência tem sido pensada, de maneira próxima ao que aponta Larrosa, ou seja, é aquela que exige silêncio, memória, tempo, ócio, passividade, paixão. E o sujeito dessa experiência tem algo como uma superfície sensível "que aquilo que acontece afeta de algum modo, produz alguns afetos, inscreve algumas marcas, deixa alguns vestígios” (LAROSSA, 2002, p.24). Esses vestígios são efeitos que se dão na processualidade do se constituir, nos processos de subjetivação. São linhas a serem cartografadas, o nosso desafio de pesquisa: ir ao vivido. Cartografar as linhas 
de fratura, com as quais foi possível inventar novos modos de subjetivação, novos mundos, ao produzir Matemática na imanência-vida.

Imanência-vida: aquilo que se dá junto ao plano movente do real. Vida como plano.

\begin{abstract}
A vida, como plano, é oferecedora de condições para um aprendizado. Ela, ao mesmo tempo é dupla: "um sistema de estratificação particularmente complexo, e um conjunto de consistência que conturba as ordens, as formas e as substâncias". A vida corte no caos é o real, a coexistência do atual e do virtual, é o grande meio, propiciadora de tantos caminhos quantos forem traçados ou percorridos, os inimagináveis; é o grande plano dos acontecimentos e dos devires. É prenhe de possibilidades, fervilha de multiplicidades que saltitam e provocam danças. Por vida entende-se "a dinâmica de vir a ser, o jogo de auto-superação ou de alteração, quer dizer, de vir a ser outro, que marca transformação ou transfiguração, o movimento da vida, se define como criação", pois toda criação se dá no plano movente do real, da imanência-vida (ROOS, 2004, p. 3 - grifo nosso).
\end{abstract}

$\mathrm{Na}$ dinâmica de vir a ser, no jogo da imanência-vida, a experiência se dá ao ser acionado o dispositivo Experimentoteca de Matemática.

A pergunta que logo vem é: o que é um dispositivo?. Essa questão não nos assolava, pois, a princípio, o que nos passava é que o espaço físico ocupado no fazer dos bolsistas do TP e dos escolares era o que constituía o que chamávamos de Experimentoteca de Matemática. Mas não era isso. Como na denominação não cabia o que pretendíamos, parecia que havíamos sido engolidos pela língua. Nossa indagação de pesquisa já trazia: "no dispositivo Experimentoteca de Matemática". A contração da preposição em com o artigo $o$ nos levou a visar um espaço territorial fixo em que pousaríamos nossas atividades. A língua nos levou para o lugar onde iriam se estabelecer as atividades envolvendo bolsistas e escolares.

Porém, no encaminhamento das atividades, mostrou-se a necessidade de, vez por outra, mudarmos o local do encontro das sextas, ou seja, alterar o espaço físico. As nossas idas para casa com um corpo tensionado, afetado, amargurado, feliz, indagador depois de cada encontro das sextas, a escrita de nossos relatórios e as nossas leituras e estudos nos faziam indagar: será no dispositivo?

A formulação da questão de pesquisa começava a se fazer questão. Voltamos a ela. Compreendíamos que a questão acionadora do pensar desta pesquisa trazia "através da experiência no dispositivo Experimentoteca de Matemática”. Não era o no, sim o através. Um através, uma passagem, um per do percurso, da experiência e do perigo de exposição com o acionamento de um dispositivo.

Então, agora sim, vinha a questão: o que é um dispositivo? 
Em Microfísica do Poder, Foucault, ao ser questionado a respeito da função metodológica do dispositivo, responde ser o dispositivo uma rede que engloba elementos heterogêneos como discursos, instituições, regulamentos, leis, enunciados científicos, proposições morais, filosóficas, filantrópicas, o dito e o não dito. $\mathrm{O}$ dispositivo estabelece um nexo entre esses elementos heterogêneos, demarcando a natureza da relação que pode haver ou se estabelecer entre esses elementos. O dispositivo pode ser um programa de uma instituição. A Educação Escolar é um programa, um dispositivo. E o dispositivo, diz Foucault, ainda pode aparecer com um sentido contrário, quando é tomado como "elemento que permite justificar e mascarar uma prática que permanece muda; pode funcionar como reinterpretação desta prática, dando-lhe acesso a um novo campo de racionalidade" (FOUCAULT, 1979, p. 244). Dentro do dispositivo Educação Escolar, outros dispositivos ora justificam, ora mascaram uma prática, ou reinterpretam essa prática, fazendo com que ela fique muda. Aqui, dentro do grande dispositivo educacional, há os projetos político-pedagógicos escolares; os projetos educacionais do Estado; os projetos com ajuda financeira como, por exemplo, o Bolsa-Escola; os programas de avaliação em larga escala; os currículos escolares em âmbito estadual ou nacional, como o Currículo Básico Comum do Estado de Minas Gerais e os Parâmetros Curriculares Nacionais.

Os dispositivos, segundo Foucault, respondem a uma demanda, em determinado momento histórico, tendo, pois, uma natureza estratégica. Tal natureza estratégica nos leva a compreender que o dispositivo é capaz de uma manipulação das relações de força, através de certa racionalidade e organização, com certo propósito: "seja para desenvolvê-las [as forças] em determinada direção, seja para bloqueá-las, para estabilizá-las, utilizá-las etc" (FOUCAULT, 1979, p. 246). Dessa forma, o dispositivo está inscrito em um jogo de poder e, portanto, ligado a um saber que dele nasce e também o condiciona. Na Educação Escolar, nos anos 90 do século passado, vimos ser acionado o dispositivo Parâmetros Curriculares Nacionais, atendendo ao jogo de poder da política neoliberal, desenvolvendo-se, assim, um modo de ser aluno e de ser professor submetidos diretamente ao mercado econômico e ao poder do capital.

O dispositivo é disruptivo: faz nascer. O funcionamento estratégico do dispositivo faz surgir através dele efeitos não previstos. Foucault (1979, p. 245) irá dar como exemplo o dispositivo prisão. Tal dispositivo, visto até certo momento como o mais eficiente e racional para conter a criminalidade, produziu um efeito não previsto: um meio delinquente. "A prisão funcionou como filtro, concentração, profissionalização, isolamento de um meio delinquente". 
Deleuze (1990) também questiona o que é o dispositivo. Tomando os estudos foucaultianos, irá dizer que os dispositivos têm cinco dimensões: curvas de visibilidade, curvas de enunciação, linhas de forças, linhas de subjetivação e linhas de fratura.

Os dispositivos "são máquinas de fazer ver e de fazer falar" (DELEUZE, 1990, p. 1), têm seus regimes de luz para fazerem ver sem ser vistos e possuem seus regimes de enunciação - ciência, gênero literário, um estado de direito, um movimento social. O dispositivo não é composto por sujeitos nem objetos, mas por regimes "que devem se definir para o visível e para o enunciável, com suas derivações, suas transformações, suas mutações" (IDEM, p. 2). As linhas de força que compõem os dispositivos organizam o ver e o enunciar. Estão aí as relações de poder anunciadas por Foucault. Assim como o poder, o dispositivo compõe com o saber.

Já a linha de objetivação é aquela que solicitou a Foucault uma torção no pensamento: estaria ele só preocupado com os contornos definitivos resultantes dos modos de sujeição através de regras de coerção? É quando Foucault irá pensar em uma dobra da força.

\begin{abstract}
Transpor a linha de força, ultrapassar o poder, isso seria como que curvar a força, fazer com que ela mesma se afete, em vez de afetar outras forças: uma "dobra", segundo Foucault, uma relação da força consigo. Trata-se de "duplicar" a relação de forças, de uma relação consigo que nos permita resistir, furtar-nos, fazer a vida ou a morte voltarem-se contra o poder. Foi o que os gregos inventaram, segundo Foucault. Não se trata mais de formas determinadas, como no saber, nem de regras coercitivas, como no poder: trata-se de regras facultativas que produzem a existência como obra de arte, regras ao mesmo tempo éticas e estéticas que constituem modos de existência ou estilos de vida [...]. É o que Nietzsche descobria como a operação artista da vontade de potência, a invenção de novas "possibilidades de vida" (DELEUZE, 1992, p.123, grifo nosso).
\end{abstract}

Assim, as linhas de subjetivação se mostram presentes no dispositivo, um processo, uma produção, uma criação na imanência-vida. Uma linha de fuga que, permitindo outras configurações provisórias, "tem que se fazer, contanto que o dispositivo o permita ou possibilite" (DELEUZE, 1990, p. 3). Um escape às outras linhas, às outras dimensões. Escape à luz que tudo vê e à língua, que tudo enuncia, produzindo linhas de fratura. Outros dispositivos, novos agenciamentos a novos poderes e novos saberes que podem levar a novos modos de subjetivação ainda por vir.

Nome próprio: Experimentoteca de Matemática. Efeito: dispositivo Experimentoteca de Matemática. Efeito produzindo efeitos. 


\section{Do Tangram à maquete...}

Encontros de sextas-feiras

$2^{\circ}$ Encontro. A atividade proposta era representar, através do Tangram, as imagens que estavam no papel. Um dos escolares, que se mantinha sempre calado, mesmo em grupo, não se envolveu, não quis participar. Ficou ao longe, observando aos outros. Outro escolar que dissera ter gostado mais ou menos do encontro anterior, demonstrou grande interesse, retirou a "armadura" que o cobria e se rendeu ao Tangram. Suas mãos trabalhavam incessantemente na busca pelos desenhos a serem representados. Ao final de nossa atividade, escutamos da voz de uma das escolares que nossos encontros poderiam durar mais tempo.

Em uma grande preparação: era assim que nos sentíamos, bolsistas e equipe executora da pesquisa. Tínhamos como um de nossos objetivos a possibilidade de produção matemática durante os encontros com os escolares. Então, partimos de um material didático já bem conhecido em nossas salas de aula de Matemática: o Tangram.

A primeira proposta de trabalho foi a de que os escolares produzissem figuras a partir de modelos preestabelecidos. Ficamos por aí durante um encontro. Nas grandes mesas, as duplas tentavam, utilizando as sete peças do Tangram, montar os modelos. Alguns se envolviam, outros se distanciavam e não arriscavam. Esse foi um dos encontros que levou com que se colocasse em questão como a produção matemática estava acontecendo ali, se acontecia ou não. E, se ocorria, como a produção de conhecimento matemático se dava?

Colocamos em questão se aquela atividade não estava fazendo com que os escolares ficassem presos aos modelos. Parecia, então, que ela não proporcionava um modo inventivo de lidar com as peças. Porém, ouvir uma das escolares dizer que poderíamos ter mais tempo para os nossos encontros mexeu ainda mais com o que nos ocupava. Não se tratava do sujeito aprendente e um objeto a ser desvelado. Tratava-se do entre. Precisávamos exercitar mais. Repetir. Insistir.

Insistimos com o Tangram. Ele continuou no encontro seguinte. Dessa vez entregamos a cada escolar um Tangram e solicitamos que, individualmente, produzissem uma figura sem, no entanto, dar o modelo. Depois que fizessem tal figura, ela deveria ser desenhada em uma folha de papel para ir à nossa exposição.

Um escolar fazia figuras que havia esboçado na semana anterior sem estar, naquele momento, com o modelo. Outros resistiam. Insistimos. As figuras foram surgindo nas produções individuais. Triângulos, quadrados e paralelogramos deram forma a barco, mulher, casa, coelho. Uma invenção. 
$3^{\circ}$ Encontro. Figuras prontas. Momento de anunciar o que se produzira. Depois de muita insistência, um escolar, que se mantivera silencioso durante toda atividade, diz: "Eu fiz uma mulher rezando". Outro, que durante a atividade conversava e brincava, ao ser solicitado que falasse a respeito do que havia produzido, silencia. Tentamos adivinhar e ao perguntarmos: "Centopeia?", a cabeça balançou em afirmação. Foi o corpo respondendo. Já o menino que se rendera ao Tangram, sempre surpreendente em seus vários tons de humor, disse: "Eu fiz a casa do meu tio, Osama!".

Nossa inquietação com o primeiro encontro e o que havia sido produzido com ele se deu por problematizarmos se aquele material, utilizado daquela forma, não estaria proporcionando o que muitas aulas de Matemática já frequentadas por nós faziam e que sabemos ainda fazer: Siga o modelo!. Ou seja, a prática de uma técnica. Compreendíamos que uma proposta assim não passaria de uma forma representativa de produzir algo ou alguma coisa, seja lá o que fosse. Então, mesmo sem ter segurança que era isso que se dava, partimos para uma proposta na qual eles poderiam tomar o mesmo recurso e produzir com e através dele. E isso se deu, sem que negássemos, porém, o primeiro momento. Percebemos que, também no primeiro encontro, efeitos tinham sido produzidos como, por exemplo, memorizar modelos e poder representá-los uma semana depois. Os encontros se ligavam, através da perturbação que no segundo se impôs. Os escolares, agora, inventavam problemas. Nos encontros que vieram em sequência, o Tangram continuou presente. Uma nova proposta foi feita, por conta do que se dava entre os escolares. É necessário falarmos a respeito do que nos motivou a continuar, por mais alguns encontros, com aquele material didático.

Durante as atividades em grupo ou individuais, percebíamos que os escolares se atacavam verbalmente, o que parecia apresentar em um tom de desvalorização do que o outro estava fazendo ou por aquilo que não se conseguira produzir. Junto disso, ficava evidente, também, um desmerecimento em relação ao bairro em que o colega morava. O interessante é que pensávamos que, como os escolares frequentavam a mesma escola, eram oriundos do mesmo bairro. Tal fato não se confirmava, os embates eram constantes, o que nos incomodava. Tentamos não nos colocar em posição de apaziguadores. Buscamos, então, no próprio embate, nossa proposta de trabalho. Nada de duplas ou trabalho individual, o trabalho seria coletivo. Levamos o mesmo material: vários jogos de Tangram e apenas uma folha que receberia o trabalho de todos os escolares. 


\begin{abstract}
Encontros de sextas-feiras $4^{\circ}$ Encontro. Surgiu a ideia de produzirmos, a partir das peças do Tangram, uma "cidade”. Para tanto, a escolha dos componentes dessa cidade seria dos adolescentes. Assim foi feito. Um escolar opta por fazer uma escola. Outro reprova: "Escola não!”. E a escola não entra na lista. Das falas deles, surgiram: casa, rua, prédio, hospital, escola, ponto de ônibus, carro, praça, paisagem, banco, loja, museu, supermercado, lixo, rio, árvore, farmácia e briga. "Briga?”, esse foi o questionamento de um dos bolsistas. Surpresa. Espanto. E na voz de um dos adolescentes a resposta: "Briga sim, pois onde moro é o que mais tem. Você acha o quê? Nem tudo é perfeito não”. Escolheram o que fazer.
\end{abstract}

O dispositivo Experimentoteca de Matemática em sua estratégia já parecia apresentar disrupções, efeitos, possibilitando novos modos de estar ali naquele coletivo. O que se atualizou nos encontros fez com que nos dispuséssemos a experimentar outros modos de estar presentes no movimento das relações de forças que se dava, como também as atualizações provisórias que se mostravam. Para tanto, tínhamos que nos desprender dos rostos já formados em outros dispositivos. Desfazendo-se do rosto-aluno, do rosto-professor, do rostobolsista. Ali, na atividade, ao anunciarem os elementos que iriam compor a cidade, os escolares se desnudam e apresentam a briga como um elemento de seu existir. Já a escola, por eles tão conhecida ou reconhecida, é eliminada. Produzem uma nova linha vida, um escape, na intersecção, margeando, arrebentando e cercando. A bolsista, surpreendida, questiona um viver. O escolar se expõe na imanência-vida. Escolares, bolsistas e coordenadora pinçam outros modos de viver naquele território existencial em produção.

Encontros de sextas-feiras $4^{\circ}$ Encontro. Uma produção coletiva: grupo sentado ao chão em torno de duas folhas de papel pardo. Duas escolares produzem, com detalhes, um prédio. Uma delas deita-se ao chão, o corpo rende-se à produção. A outra vai acompanhando. Com o desânimo da primeira, a segunda aceita parar. Outro escolar vai comandando a produção de bonecos, no entanto, em vários momentos insiste para que o amigo, que se mantém sempre silencioso, também produza. Um menino, silencioso, recebe o incentivo

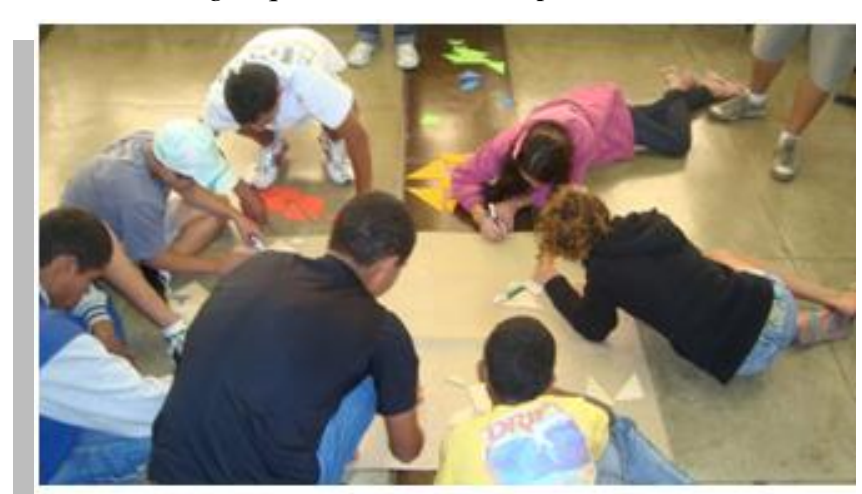

Figura 2 - Produção coletiva com o Tangram. de um colega: "Você consegue!"; "Faz assim, oh!”. No entanto, o colega termina sozinho a produção de um boneco e começa a desenhá-lo no papel pardo. Abre uma questão aos outros: "Pode pôr o escudo do Flamengo?". Apenas um responde: "Pode, mas tem que fazer direito". E o boneco recebe o escudo do Flamengo.

Três escolares produzem juntos. Um deles parece não se envolver na atividade. Em tom jocoso, os dois mais falantes referem-se em relação ao terceiro: "Ele só viaja". E o escolar mantém seu silêncio. A produção não foi toda finalizada. Combinamos expô-la, avisando que ainda estaria em construção. Ao final de nosso encontro é solicitado que todos ajudem a colar o que haviam produzido no mural. Apenas o menino que só viaja e o menino do boneco flamenguista ficaram até o final nos ajudando. O material produzido vai para o nosso quadro de exposição. 
Aquela cidade ficou em exposição com um dizer: Em construção. Um dizer do movimento que nos fazia desacostumar dos nossos lugares até então estabelecidos. Expor uma construção. Expor mundos desabando com a experiência em um vivido, em uma invenção de

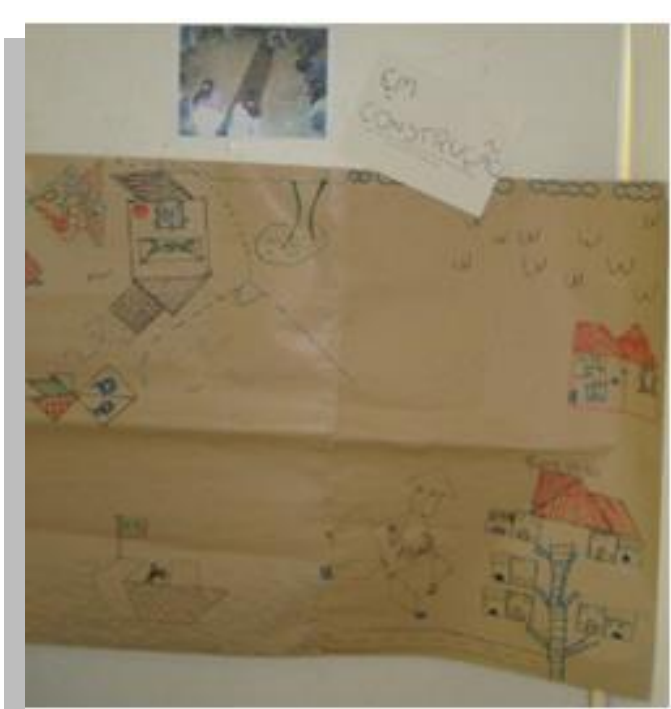

Figura 3 - Cidade em construção. modos outros de produzir um si e um mundo ao produzir Matemática. Não foi preciso dizer: "Faremos isto!". Apenas insistimos sem falação, abolindo a técnica e o modelo a ser atingido.

No material que estava exposto não houve um ajuste posicional entre as produções individuais ou das duplas ou dos trios. Tampouco houve preocupação em medir e estabelecer uma proporcionalidade entre peças. Havia pessoas maiores do que as casas, o mar e a árvore não tinham o mesmo referencial posicional. Apenas dois escolares atentaram para essas características.

Algum tempo passou entre aquela produção e nosso próximo encontro por conta das férias escolares. Quando do retorno, decidimos partir do que estava em construção. Os escolares retomaram àquela produção realizada na folha de papel pardo e começaram a observá-la. Tínhamos como proposta que aquilo que estava no papel se apresentasse em três dimensões. "Uma maquete”, disse um escolar. Assim fizemos, mas sem a preocupação com a escala. Durante algumas semanas, o que estava no plano ia tomando forma através de placas de isopor e caixas. Por fim, uma nova produção ia se apresentando: árvore, jardim, casa, prédio, carro, boneco flamenguista.

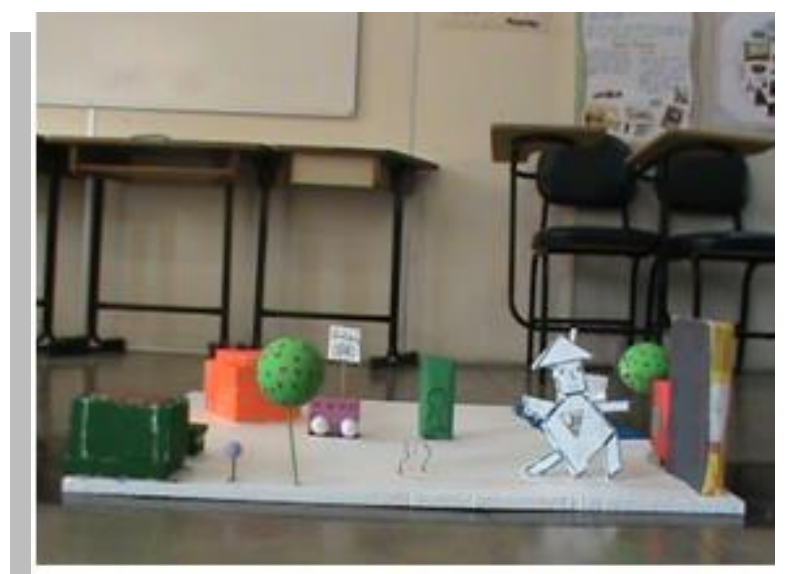

Figura 4 - Primeira maquete.

A partir da maquete produzida, um novo exercício: as diferentes visadas possíveis a um objeto tridimensional. $\mathrm{Na}$ maquete observávamos, por exemplo, no prédio que havia sido confeccionado em uma caixa de biscoitos, que a dupla de escolares que o produzira só identificara a frente do prédio com janelas e portas, já as laterais e o fundo continuavam como caixa de biscoitos. O boneco flamenguista só era visível como 
boneco pela frente, na lateral e na face que representaria as costas do boneco só vislumbrávamos isopor, o que também aconteceu com o barco. Percebíamos que a geometria plana se destacava nas faces que expunham a frente dos objetos, apesar de a maquete objetivar apresentá-los em três dimensões. Linhas de outros dispositivos se mostravam: na educação matemática escolar, a grande ênfase ainda é dada à geometria plana, abolindo o mundo em que vivemos.

Isso nos impulsionou a um novo trabalho, a uma nova produção. Levamos conosco duas caixas em forma de paralelepípedo reto-retângulo e um cilindro. Antecipadamente, esses objetos foram posicionados juntos e fotografados em vários ângulos para que pudessem ser vislumbradas as vistas frontais, laterais e superior. As fotos foram expostas em um datashow. As duplas de escolares eram convidadas a posicionar os três objetos conforme o que estava sendo mostrado na foto, devendo ainda dizer de que posição ela havia sido retirada. As duplas não mostraram nenhuma dificuldade em realizar a tarefa.

Depois dessa atividade, retornamos, no mesmo dia, à maquete produzida. A maquete também havia sido fotografada em vários ângulos, permitindo visualizar não apenas cada objeto em suas diversas vistas, mas também a maquete como um todo. Embora tivéssemos, assim, vistas frontais, laterais e superiores de todos os objetos, algumas fotos não levavam ao seu reconhecimento.

Demos continuidade à atividade projetando essas fotos para que os escolares as observassem e falassem a respeito do que observavam. Vários foram os comentários: alguns apontavam para o que poderia ter sido feito, outros, em tom de comparação ou de desdém, referiam-se às produções dos colegas, tendo surgido, ainda, algumas justificativas para os seus próprios trabalhos. Nosso exercício foi o de buscar pelo que poderia ser produzido a partir dali, mas não pelo que faltava àquela produção, dizendo repetidas vezes: “Essa já é uma produção. Como podemos falar dela? Mas, não, para arrumar o que falta e o que ficou feio. Mas, sim, para produzir outra coisa”. Os comentários se intensificaram trazendo a desproporcionalidade dos elementos da maquete e também um não reconhecimento, através da foto, do objeto representado. "Olha lá, só uma rua!" quando foi apresentada a vista superior de uma parte da maquete na qual só estava o boneco, sendo possível vislumbrar o isopor da placa com a qual fora confeccionado e a rua na qual estava. "O barco parece um ratinho", referindo-se à foto de uma das laterais do barco que estava apenas em isopor. "É uma torta de biscoito, tinha que colocar um papel atrás”, diz um escolar referindo-se à face que representaria os fundos do prédio que ainda estava na caixa de biscoitos. 
Então, um escolar, em meio à conversa que travávamos, já percebendo, pelo encaminhamento, que a proposta de trabalho que estava por vir era a produção de uma nova maquete, diz: "Fazer outra maquete? Ah não?! Tô com a cabeça doendo de tanto pensar". De outro escolar surge a ideia de construirmos, nessa nova maquete, um morro. Nesse momento, pensa-se nos materiais a serem utilizados para um formato tridimensional. Então, o primeiro, já mais animado, dá a ideia de produzirmos um bairro com partes do bairro de cada um dos escolares, dos bolsistas e da equipe executora da pesquisa. A ideia foi aceita por todos e cada um escolhe o que trazer do seu bairro. Nossos lugares de nossos bairros são então escolhidos e listados: o cemitério, a igreja, a padaria, a praça, o campo de futebol, a própria casa, o posto de gasolina, o jardim, os becos. E o menino que está sempre em silêncio, o menino silencioso, escolhe, depois de insistirmos, a escola.

Nesse mesmo encontro trouxemos o Google $\mathrm{Maps}^{5}$ projetando, em uma tela branca para que pudéssemos vislumbrar, bairros, ruas, relevos, na tentativa de trazer as três dimensões para nossa conversa. No entanto, o encaminhamento que havia se dado nos levou para além disso. O Google Maps nos ajudou a conversar a respeito do nosso novo empreendimento: produzir um bairro com elementos de todos os bairros das pessoas que compunham aqueles encontros.

Mapas recortados de Juiz de Fora foram projetados naquela tela. Focamos principalmente na região dos bairros dos escolares. O menino que antes estava desanimado se destacou nesse momento. Levantou-se, foi até a frente da projeção e ajudou a localizar os bairros de cada um, percorrendo caminhos e ruas conhecidas em seu cotidiano. Seus dedos

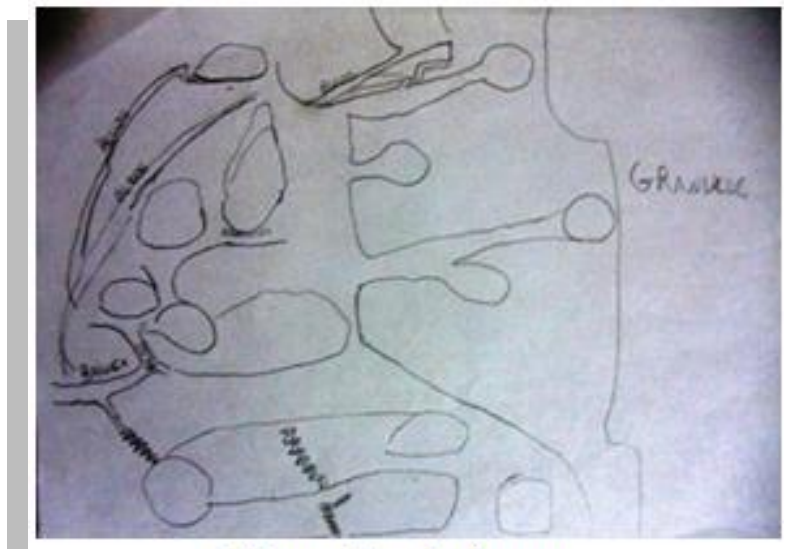

Figura 5 - Os becos. apontavam incessantemente para os lugares. "É aqui". "Mais pra cá”. "Mais pra lá”. "Isso". "Ali é o Cristo". "Aqui é onde moro". Um menino GPS ${ }^{6}$.

Procuramos localizar, no bairro de um dos escolares, o local escolhido por ele: os becos. Entretanto, não conseguimos. E ele, o menino dos becos, argumentou: "Não dá pra ver, é tudo muito junto”. Em silêncio, em meio

\footnotetext{
${ }^{5}$ O Google Maps está disponível em http://maps.google.com.br/. Através dele há a possibilidade de escolher um endereço (país, cidade, bairro, rua) e visualizar um mapa em uma visão superior. Porém, poderíamos ainda usar um dos seus recursos, o Google Earth, que permite a visualização de terrenos e construções em três dimensões.

${ }^{6}$ Global Positioning System (Sistema de Posicionamento Global).
} 
à conversa dos outros, projetou como seriam os becos.

Ficou, então, o seguinte combinado: visitaríamos, juntos, os bairros de todos para fazermos as medições reais de cada local escolhido.

Em nossas reuniões de estudo e planejamento, sentíamo-nos desconcertados com o como preparar e o como desenvolver nossas atividades. Parecia-nos que nosso amparo sempre se dava de modo muito fluido e ocasional, o que nos desestabilizava. Por outro lado, isso nos impulsionava porque, embora fosse um imprevisível, era cuidado. Estávamos nos desacostumando dos modos de ser professor e dos modos de almejar a ser professor. Não estabelecíamos o modelo a ser alcançado. Havia, no entanto, uma organização e um investimento no implicar-se com/na experiência.

Em nossos encontros com os escolares, como o que acabamos de relatar, nossos movimentos eram ainda mais cuidadosos, procurando criar um modo de estar ali desconectado dos valores como os de o melhor modo, o mais belo, o poderia fazer assim, o certo e o errado. Negávamos a falta. O que nos importava era o aqui, o tempo presente, em um cuidado intenso com a dimensão do viver em um produzir-se potentemente ao produzir Matemática. A aprendizagem se dava na duração, no tempo da experiência, no movente das forças que são no mundo, na imanência-vida. A rede acionada pelo dispositivo Experimentoteca de Matemática engendrava novos movimentos e atualizações.

Nosso modo de acionar o dispositivo Experimentoteca de Matemática foi rodear, mantendo a tensão, porém não usando os discursos já instaurados no âmbito escolar como o de que se é capaz por já ter idade ou conhecimento suficiente para tal, ou o de ser possível se houver dedicação e comprometimento. Nossa dedicação e compromisso eram acionados ao fazermos. Percebíamos que isso também se dava com os escolares. Nosso território existencial era ampliado, destituindo as linhas duras de outros dispositivos. Rodeávamos e pinçávamos linhas de vida que assujeitavam a modos esperados de ser professor e ser aluno, curvando-as sobre si mesmas, em uma dobra, em uma produção artista de um si e de um mundo.

Encontros de sextas-feiras $12^{\circ}$ Encontro. Cada um destaca o material que precisa para produzir o que foi escolhido. Anotamos. Vamos providenciar. Mais planejamento. Ressalta-se a importância de pensar que tudo aquilo que havíamos escolhido para produzir a maquete deveria caber em duas placas de isopor. O menino GPS reage, une suas mãos simbolizando uma porção e diz: "Então eu vou usar só isso de areia?!", referindo-se ao seu campo. Sente-se incomodado. A necessidade de pensar em proporção está surgindo, apresentando-se como problema. 
Para dar encaminhamento à proposta de trabalho por nós articulada, marcamos uma saída, que foi chamada de Um passeio pelos nossos bairros. Fizemos uma lista com doze bairros a serem visitados. Porém, entre o encontro da decisão em fazer uma maquete, passamos por um encontro de preparação para o trabalho para pensarmos o material que iríamos utilizar e, só então, veio o passeio aos bairros. Decidimos visitar os bairros mais próximos. Isso nos levou a um número de sete bairros, os dos escolares e o da coordenadora. Já no encontro de preparação, o menino dos becos não apareceu nem para ir ao passeio. Depois de algum tempo, soubemos, pelos colegas, que ele considerava que seu bairro não seria um lugar seguro para visitarmos.

Encontros de sextas-feiras $14^{\circ}$ Encontro. Um passeio pelos nossos bairros. O dia de sol intenso prometia muito calor. Passamos pelo cemitério do bairro São Pedro, pela escola do bairro Santos Dumont, pela praça no mesmo bairro, pela casa de uma escolar no bairro Serro Azul, por um campo no bairro Fátima e, por fim, por uma igreja no Democrata.

Para acompanhar a atividade, cada escolar levou, em suas mãos, um caderno para anotações e um lápis. Levamos uma trena. Ao pararmos em um dos pontos combinados, a câmera fotográfica era entregue nas mãos do escolar que havia escolhido tal local. A escolar que escolhera o cemitério foi a primeira a estar com a câmera fotográfica em mãos. Percorreu todo o cemitério com uma amiga. Muitas fotos foram tiradas. Já nas primeiras medições realizadas, a escolar questionou: “Como é que é?". A escolar se referia aos centímetros e às polegadas que se mostravam na trena. Discutimos as unidades, ali mesmo, no cemitério.

O menino silencioso havia escolhido a escola para apresentar na maquete. Negou receber a câmera para fotografar, dizendo em tom baixo de voz: "Não quero fazer isso não". Não fez. Participou timidamente das medições realizadas. Ao anotar em seu caderno o que estava sendo medido, verificamos que os números estavam ali soltos, não faziam referência ao que correspondiam. Então, foi feito rapidamente e a mão livre, pela coordenadora, um esboço da planta baixa da escola utilizando quadriláteros, e o escolar foi indicando, nesse desenho, as medições realizadas.

Saímos da escola e seguimos para a praça no mesmo bairro. A câmera fotográfica foi entregue ao escolar que iria fazer a praça na maquete, o menino que só viaja. Mas ele também rejeitou tal tarefa, dizendo: "Não sei mexer com isso não". Rapidamente recebeu algumas orientações e saiu pela praça fazendo suas fotos. Depois acompanhou as medidas realizadas na quadra e na rampa de skate e fez as anotações apresentando dificuldades para lidar com a 
escrita das unidades. Afirmou que iria representar apenas a quadra e a pista de skate na maquete. Tirou fotos desses pontos da praça.

No bairro Serro Azul fomos recebidos pelos irmãos de uma das escolares. A escolar ajudou nas medidas possíveis de serem realizadas na fachada de sua casa. Como não tínhamos acesso aos fundos da casa nem ao último andar, estimamos. Para o comprimento da frente aos fundos, fizemos a estimativa pela quantidade de cômodos. E, para a altura, discutimos a medida do pé-direito de uma casa. Essas discussões se deram na rua.

Dali, seguimos para o bairro do menino GPS. Ele foi orientando o motorista. O campo de futebol encontra-se em uma área enorme, o que chamou a atenção de todos, mas o motorista que nos conduzia se destacou, dizendo: "Vocês vão medir isso?”. Os bolsistas responderam, gritando de longe para o grupo que já fazia as medições: "Vocês vão medir isso tudo?", e logo receberam uma afirmativa. Os sorrisos invadiram o ar. O temor do motorista nos impulsionava. Durante nossa estada por ali, o menino GPS mostrou com prazer sua casa, dizendo que morava com a mãe na casa debaixo e o pai na de cima.

Por fim, a igreja, escolhida pela coordenadora. Os escolares, ao vislumbrarem a igreja, espantaram-se tamanha era sua dimensão, tanto em comprimento, largura, quanto em altura, além do grande número de janelas. O grupo de escolares meninos se organizou na esquina da igreja e os outros, bolsistas, mediam e filmavam. Terminamos as medidas possíveis de serem realizadas, fizemos as devidas anotações e retornamos à UFJF.

Encontros de sextas-feiras $14^{\circ}$ Encontro. Ao chegarmos do passeio pelos nossos bairros, servimos um lanche. Todos se sentaram e se refrescaram tomando refrigerante e se deliciando com biscoitinhos. Para finalizar, perguntamos se haviam gostado de nossa saída e na voz da escolar que iria fazer sua casa na maquete veio: "Eu até pensei em não ir, mas que bom que fui". Todos afirmaram terem gostado da experiência. Do menino que só viaja, ao se despedir, veio: "Semana que vem começamos a maquete?".

A elaboração da maquete seguiu por oito encontros. A proposta de trabalho foi a de

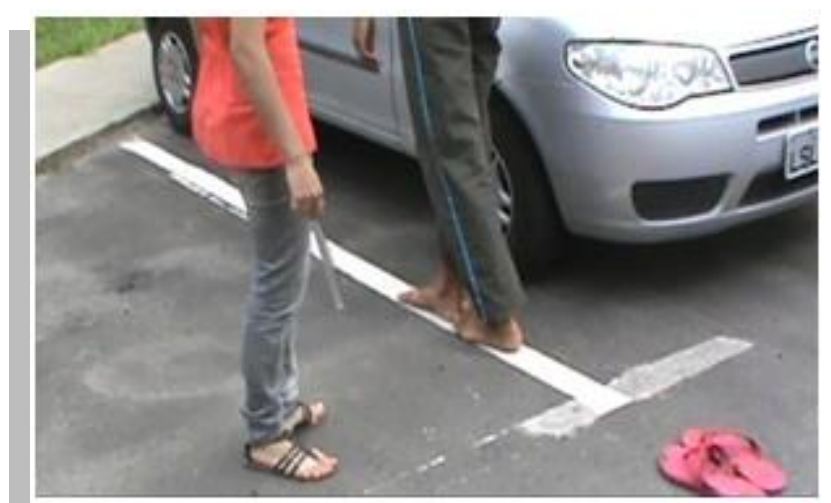

Figura 6 - Medindo com os pés. produzirmos, inicialmente, uma escala. Porém, decidimos que não seríamos nós que iríamos definir uma escala para os escolares e, tampouco, solicitar a produção de uma. Preparamo-nos com um propósito: a produção de uma escala deveria ser um problema inventado pelos próprios escolares, deveria constituir-se como um problema. Um difícil exercício: buscar modos para que 
a problematização fosse acionada. Assim, preparamos folhas de papel pardo para que fizéssemos um rascunho do local no qual colocaríamos cada peça a ser produzida, fazendo um quadrilátero na região a ser ocupada. Isso começou a produzir alguns efeitos. Houve resistência, mas também, entrega.

Encontros de sextas-feiras $15^{\circ}$ Encontro. O menino GPS e a menina da casa sentam-se ao chão em torno do papel e juntos com os bolsistas começam o rascunho. Os outros, sentados nas carteiras, dão palpites. O menino silencioso mantém seu silêncio. O menino GPS sugere começar o rascunho pela parte mais dificil: os morros: "A gente tem que começar pelo mais difícil, pra gente tentar quebrar a cabeça, pra chegar num lugar”. Muitas falas. O menino GPS entrega-se ao movimento do pensar: em língua, em corpo. Planeja várias estratégias: "Por que a gente não bota a igreja aqui, bota uma rua subindo assim?". Seus dedos indicavam: "Começa botando umas curvas aqui, aí uma rotatória, a gente joga para um lado e pro outro”. Uma bolsista sugere começar pelas ruas. O menino GPS elabora: "Ai, vamos supor: bota uma rotatória, ai sobe pela igreja, ai a outra sobe pra cá”. Uma questão surge: "Qual é a largura de uma rua?". Outros problemas são levantados: "Nem todas as ruas têm a mesma largura. Passamos por ruas mais apertadas"; "No meu bairro é assim, passa um carro de cada vez"; "Se for avenida é mais larga”. Decidimos por seis metros, já que esta fora a medida encontrada em um dos bairros. Tínhamos um carrinho de plástico, com 2,5cm de comprimento, que foi nosso ponto de partida. "Mas, quanto é o comprimento de um carro de verdade?". "A gente vai ter que ir ao estacionamento e medir um carro, pra gente ter uma noção". "Não temos uma trena, estragou". "Medimos com passos". O corpo como objeto de medida. Medimos por pés. Um escolar mediu primeiro, anunciou: "Treze e meio". Outro, com um pé maior, prontificou-se a medir. Antes de terminar a medição, o menino GPS, diz: "O seu vai dar uns sete".

Assim, a escala foi sendo produzida em uma conversa. Uma boa escala - seja lá o que for boa - para nós, seria aquela em que a produção de todas as peças da maquete coubessem naquelas duas folhas de papel pardo coladas. Para além disso, seria aquela escala que fosse necessária de ser produzida, que fosse problema. Isso se constituiu, levamos dois encontros nessa problematização. Feita a escala, fomos à produção.

Encontros de sextas-feiras $17^{\circ}$ Encontro. Na mesa: estiletes, colas, réguas, isopor, caixas, tinta, palitos, canetas, lápis de cor, papel, papel cartão,... As mãos corriam pelo isopor, os estiletes iam e vinham próximos às mãos. Ansiedade. Prazer. Tensão. Partes, cortes, recortes, dedos, mãos... Casa, escola, paredes, praça, campo, posto de saúde, posto de gasolina. Como dar conta de apresentar onde se vive, onde se corre, onde se brinca, onde se estuda? Como dar tom a uma placa de isopor no mesmo tom da vida? Difícil... Mas, no caminhar da nossa atividade, a vida aparecia na voz de uma escolar que contava de uma nota zero na avaliação de Matemática valendo seis e no sorriso de uma das bolsistas quando recebeu a notícia. Avaliar não fazia parte da nossa rotina. As produções que fazíamos traziam, até então, o nosso jeito. Que jeito? Não sei. O desânimo de um escolar se mostrava em sua pressa ao produzir o Posto de Saúde para nossa maquete. Pintar, desenhar, terminar rápido,... Como isso se dava? Desinteresse? Nenhum modelo a ser representado?

Nossa produção continuou por mais algumas semanas. Em meio aos movimentos do fazer dos objetos da maquete, a vida ia se anunciando. Ora no silêncio de um menino que produzia com extremo cuidado a escola. Não encontrava o meio na régua. Media ou sete ou oito. No encontro com a bolsista: o sete e meio, no meio das coisas, da vida. Com um sorriso 
terminou seu trabalho e ainda ajudou aos outros. A menina da casa preocupou-se com as medidas, com a escala. Sempre falante. Entre muitos dizeres, trouxe: a mãe, os irmãos, o padrasto, a ausência do pai, a escola, o insucesso em Matemática e também o sucesso. Uma casa cheia de emendas, produzida no viver. O menino GPS se ausentou em presença algumas vezes, negou fazer, parecia não compreender o porquê de não ser obrigado a fazer. Então, em um dos encontros, tomou sua produção com cuidado e finalizou. O menino dos becos esteve conosco em alguns encontros. Justificou sua ausência em outros, dizendo: "Não dá para vir toda semana por causa do sistema. Como vou faturar meu dinheiro?". Precisava, para a maquete, da largura dos becos, mediu, abrindo os braços. Em outro encontro trouxe, em conversas com os escolares, tiros e assassinatos no bairro em que morava. Não foi preciso sussurrar. A vida podia ser narrada. Não terminou os becos, ausentou-se dos últimos encontros. Aconteceu de alguns tentarem fazer bem rápido a produção. Esses acabaram sendo envolvidos em outras, como, por exemplo: postes, orelhões, ruas...

Encontros de sextas-feiras $21^{\circ}$ encontro. Finalizações. Toques. Retoques. Detalhes sendo cuidados com muito capricho. As mãos trabalhavam incessantemente com delicadeza para que tudo ficasse pronto a tempo. Os olhos de alguns "gritavam" satisfação. Corpos quietos, inquietos, aflitos, interessados, desinteressados, atentos, desatentos, satisfeitos, insatisfeitos. Tentativas e mais tentativas. Planejamos. Mas um planejamento flexível, que modificava a cada acontecimento. Estávamos no movimento do viver.

$\mathrm{Na}$ experiência vivida em nossos encontros, linhas duras surgiam nos enunciados dos sujeitos escolarizados que ali estavam. Outros dispositivos já haviam sido acionados antes. Todos que ali chegavam já sabiam se dizer e se pensar e viver de um certo modo já esperado. Peças de xadrez, um xadrez do dispositivo escolar, da instituição escolar. Ao aluno cabe ouvir, respeitar, produzir o que a ele é solicitado, atender ao modelo esperado de bom aluno. Ao professor-coordenador cabe apresentar um saber já fechado, com suas verdades e certezas. Aos bolsistas? A eles cabe, nesse momento, treinar para chegar ao modo professor de ser.

As linhas do dispositivo escolar ficavam no não dito, mas no já conhecido, no já sabido. A luz do dispositivo Educação Escolar faz nascer o aluno que tem competências em Matemática e o professor que sabe o quê, quando e como ensinar. Faz nascer o rosto-aluno e o rosto-professor que não existe sem essa luz. Além disso, o dispositivo enuncia o que não vê. Tem seu regime de enunciação que se dá em forma de projetos político-pedagógicos, nos PCN, nos CBC... Dizem e dão forma ao que não se vê. Linhas de forças - do modelo econômico, do político, do social - aliam-se ao ver e falar, aliam-se às linhas de visibilidade e de enunciação, fazendo com que se produzam modos de ser aluno, de ser professor, de aprender e de ensinar acordados com certa verdade transcendente. 
Porém há uma mobilidade nos dispositivos, as linhas são todas linhas de variação. "O Uno, o Todo, o Verdadeiro, o objeto, o sujeito, não são universais, mas processos singulares, de unificação, de totalização, de verificação, de objetivação, de subjetivação imanentes a um determinado dispositivo" (DELEUZE, 1990, p. 5). Então, os dispositivos têm as linhas de ruptura, de fratura, que permitem que outros dispositivos sejam acionados. Fraturar, quebrar, inventar.

Um disparador, um dispositivo foi acionado: a Experimentoteca de Matemática. Com a cartografia, tem-se a proposta de acompanhar processos de subjetivação. Assim, foi possível detectar um movimento do pensar e do existir que exigiu a decisão de uma política da cognição que escapasse ao representativo, ao modelo e que possibilitasse um habitar em um território existencial, produzindo agenciamentos entre a produção matemática, a produção de um si e de um mundo. Pensar e existir coengendrados.

O dispositivo Experimentoteca de Matemática produzindo outros modos de estar naquele território existencial. Produzir um novo corpo sem amarras na imanência-vida, produzindo modos de pertencimento provisórios: nascimento, disrupção, efeitos. O dispositivo acionando a produção do conhecimento, a invenção, a produção de um si e de um mundo junto à produção matemática. A Matemática sendo produzida como problema, com problematização, por necessidade.

Foi possível, para os escolares, sair das sete peças do Tangram e produzir uma maquete. Para tanto, foi necessário trabalhar com o espaço tridimensional tão abolido nos anos do Ensino Fundamental, trabalhar com medições, com produção de escalas, com vistas de um objeto tridimensional e com proporcionalidade. Houve um repúdio às técnicas preestabelecidas. O dispositivo operou na multiplicidade dos processos em devir na experiência do encontro com o não-conhecido, desestabilizando o pensar. Dessa forma, houve a produção do novo no dizer, no fazer, no ver.

Ficamos, então, com uma questão deleuziana: podem se invocar dispositivos em que a subjetivação passe pela existência marginalizada do excluído? Respondemos: sim. Tal existência marginalizada do excluído, também provisória e precária, desmancha, quebra, fratura. E, ainda, podemos dizer que novos modos de se dizer, de se ver e de estar nas relações de forças que são no mundo podem ser acionados por esses dispositivos através de uma invenção de modos mais potentes de vida. Esses novos modos, também precários, provisórios, inventados, vão dando um tom ao viver na imanência: nossa atualidade. 
Voltemos aos nomes próprios que iniciaram este texto. Do Tangram à maquete, mas é no meio que se deu a intensidade e nomes próprios deixaram de designar sujeitos de detentores de um saber-fazer ou um ocupar-fracassar, deixaram de ser precedidos de artigos

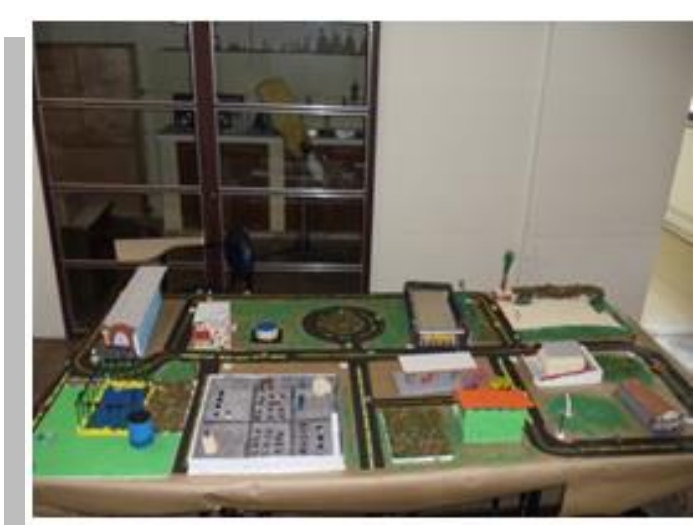

Figura 7 - Segunda maquete. definidos e de conjugar verbos. Os nomes próprios passaram a intensidades, a devires precedidos de artigos indefinidos e seguidos de verbos nos infinitivo. De a Maria ensina a uma-Mariaensinar. De o João aprende a um-João-aprender. O infinitivo como tempo do devir, não mais o tempo cronos. Sim, tempo aion, tempo do acontecimento. Uma-Maria-ensinar. Um-João-aprender. Nada falta ao artigo indefinido já que, agora, não se liga a determinado sujeito e, sim, a um nome próprio que é pura intensidade. Efeitos através da experiência acionada por um dispositivo na imanência-vida.

Por fim, um produto. Muitos efeitos. Menino que gosta de azul e menino silencioso e menino flamenguista e menina da casa e menino GPS e menino que só viaja e menino dos becos e... e...

\section{Referências}

DELEUZE, G. ¿Que és un dispositivo? In: Michel Foucault, filósofo. Barcelona: Gedisa, 1990, p. 155-161. Tradução de Ruy de Souza Dias. Disponível em: <http://pt.scribd.com/doc/7134422/o-Quee-Um-Dispositivo>. Acesso em: 14/05/2012.

DELEUZE, G. Conversações. Tradução de Peter Pal Pelbart. São Paulo: Editora 34, 1992.

DELEUZE, G.; PARNET, C. Diálogos. São Paulo: Escuta, 1998.

FOUCAULT, M. Microfísica do Poder. Rio de Janeiro: Edição Graal, 1979.

LARROSA, J. Notas sobre a experiência e o saber da experiência. In: Revista Brasileira de Educação, v. 19, p. 20-28, jan/fev/mar/abr. 2002.

ROOS, A. P. Nunca se sabe como alguém aprende.... In: II COLÓQUIO FRANCO-BRASILEIRO DE FELISOFIA DA EDUCAÇÃO - O Devir-mestre: entre Deleuze e a Educação, 2., 2004, Rio de Janeiro, Anais... Rio de Janeiro. 2004, cd-rom. v. único. 